\title{
Urgences
}

\section{Le dragueur surréaliste no 9}

\section{André Roy}

Numéro 15, octobre 1986

Épigraphiques

URI : https://id.erudit.org/iderudit/025298ar

DOI : https://doi.org/10.7202/025298ar

Aller au sommaire du numéro

Éditeur(s)

Urgences

ISSN

0226-9554 (imprimé)

1927-3924 (numérique)

Découvrir la revue

Citer ce document

Roy, A. (1986). Le dragueur surréaliste no 9. Urgences, (15), 31-31.

https://doi.org/10.7202/025298ar

Ce document est protégé par la loi sur le droit d'auteur. L’utilisation des services d'Érudit (y compris la reproduction) est assujettie à sa politique d'utilisation que vous pouvez consulter en ligne.

https://apropos.erudit.org/fr/usagers/politique-dutilisation/
Cet article est diffusé et préservé par Érudit.

Érudit est un consortium interuniversitaire sans but lucratif composé de l’Université de Montréal, l'Université Laval et l'Université du Québec à Montréal. Il a pour mission la promotion et la valorisation de la recherche. https://www.erudit.org/fr/ 


\title{
André Roy LE DRAGUEUR SURRÉALISTE \\ NO 9 \\ (Texte à grande vitesse)
}

\author{
Explorer l'âme, le coeur, le cul \\ En deux temps, trois mouvements. \\ Roger Des Roches: Le soleil tourne autour \\ de la terre
}

Il y a qu'il y aurait par exemple la pluie, la lumière décidant des formes décisives de ton corps et les événements qui coulent, il $y$ a surtout que j'ai des yeux et que je ne peux t'empêcher de penser, ni de courir ni de penser, de rouler et de penser. Propice à la vitesse et encore plus volatil. Les mêmes sueurs exactes et le même sexe bleu comme le paysage avant la Terre, avant que le ciel ne se brise en se fermant sur nos amours. Il y a que nos prétextes de vivre ne sont pas clairs malgré le silence qui se crée là-bas. Il y a que mon intérieur fait des choses! J'étudierai la préhistoire de mon coeur respirant deux ou trois fois pour toi. L'espace de l'âme dépasse-t-il celui du cul? Oui, tu continues de vivre avec mes pensées sur ton dos, ton corps obéit encore à la gravité de la Terre.

Responsable de chaque événement, de chaque amour entassé dans les événements. Sensible à l'air et encore plus inquiet. Oui, toujours les mêmes ombres du dragueur et son corps qui roule, se déroule, susceptible de se défaire dans l'exploration du temps et du mouvement. 